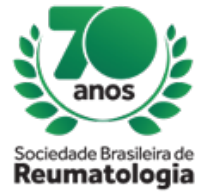

\title{
CROWNED DENS SYNDROME: A CASE REPORT
}

Luan Felipe Lückmann (UFPR, Curitiba, PR, Brasil), Nathan Marostica Catolino (UFPR, Curitiba, PR, Brasil), Ana Luisa Woidello Miyazima (UFPR, Curitiba, PR, Brasil), Isadora Welter Pioresan (UFPR, Curitiba, PR, Brasil), Mariana Lechitzki (UFPR, Curitiba, PR, Brasil), Keoma Azevedo Sabião (UFPR, Cutitiba, PR, Brasil), André Luís Souza Andretta (UFPR, Curitiba, PR, Brasil), Ana Beatriz Artigas Guimarães (UFPR, Curitiba, PR, Brasil), Maxwell Cassio de Albuquerque Pessoa (UFPR, Curitiba, PR, Brasil), Salun Coelho Aragão (UFPR, Curitiba, PR, Brasil), Natalia Pereira Machado (UFPR, Curitiba, PR, Brasil), Eduardo Santos Paiva (UFPR, Curitiba, PR, Brasil)

\section{BACKGROUND}

Clinical syndromes may be associated with deposition of calcium pyrophosphate crystals dihydrate (CPP) in connective tissues. Crowned dens syndrome (CDS) is a rare presentation involving the presence of CPP around the atlantoaxial joint, which is characterized by acute or recurrent severe cervical pain, neck rigidity, and associated fever, in addition to increased inflammatory markers. Identifying CPPs by computed tomography (CT) is essential to exclude the differential diagnosis, such as polymyalgia rheumatica, giant cell arteritis or, less frequently, meningitis, cervical dyscitis or inflammatory spondyloarthritis We present a case report of a male with recurrent cervical pain irradiated to the shoulder and upper limbs, with reduced cervical mobility, whose MRI indicated CDS.

\section{CASE REPORT}

Caucasian man of 77 years old has been complaining of cervicalgia and occipital headache for two weeks, associated with reduced mobility of the neck. He denied trauma or physical effort, as well as fatigue or weight loss, changes in his level of consciousness or visual deficit. He has been attending an outpatient Neurology clinic for a diagnosis of chronic cervicogenic headache and neuralgia of the major and minor occipital nerve. In the osteoarticular evaluation, pain was noted on palpation of trapezius muscles and cervical and occipital region. Limited cervical mobility in all directions it was observed. Stroke and infectious process were excluded. Their evidence of inflammatory activity was increased (ERS $88 \mathrm{~mm}$ in the first hour and PCR $10.9 \mathrm{mg} / \mathrm{dL}$ ). CT scan of the and CSF analysis were performed, both of which were normal. The rheumatology department was consulted, and a cervical MRI was requested (Figure 1). The examination showed extensive bone lysis anterior arch of C1 and mainly odontoid process, associated to the formation of soft tissue injury with heterogeneous enhancement by contrast, previously bulging the dural sac and moderately reducing the amplitude of the vertebral canal. With this, our main diagnostic hypothesis became C1-C2 CPP. The patient had improvement with the use of prednisone 10mg a day and colchicine $0.5 \mathrm{mg}$ a day. Their inflammatory tests were progressively reduced until they normalized about 1 month later.

\section{CONCLUSION}

This case draws attention due to the complexity in the diagnosis of a patient with cervicalgia, headache and fever when the main hypotheses are excluded and places CDS as an important differential diagnosis that can be identified by the appropriate imaging examination. 